\title{
The Model of Teaching Material for Poetry Study Based on Character Education
}

\author{
$1^{\text {st }}$ R. Nuryani \\ Indonesian Language and Literature \\ Education, STKIP Muhammadiyah \\ Bogor \\ Indonesia \\ rinanoeryanii@gmail.com
}

\author{
$2^{\text {nd }}$ S. Muhammad \\ Indonesian Language and Literature \\ Education, STKIP Muhammadiyah \\ Bogor \\ Indonesia
}

\author{
$3^{\text {rd }}$ Sofiatin \\ Indonesian Language and Literature \\ Education, STKIP Muhammadiyah \\ Bogor \\ Indonesia
}

\begin{abstract}
The implementation of learning literary studies courses can be directed at efforts to implement education and student character development. Development of teaching materials is essentially part of overall curriculum development. If you expect graduates of a certain level of education to have the desired character qualifications, a curriculum designed to achieve that goal must also be developed based on the principles of character values. To be precise, the developed learning materials must also meet these demands. That is, the design and development of teaching materials must be deliberately designed to produce graduates who are cultured and of character. Character education is one of the supporters of Indonesia's national education goals. When the lecturers in the class have implemented their learning with character education (contained in the RPS lecturer Poetry Study course), however teaching material also needs to be developed with a character education approach. Therefore, in this study developed teaching materials for the study of poetry based on character education.
\end{abstract}

\section{Keywords-Teaching, Poetry Study, Character}

\section{INTRODUCTION}

Learning languages means learning to communicate according to context, whereas learning to write means learning to respect humans and their values. The ability to communicate both orally and in writing, can be learned through learning Indonesian language and literature. In learning Indonesian language and literature, students are directed to master the communication skills that are essential for daily life.

In addition to language learning, literary learning is also important [1]. In learning literature there are complex life values that can be emulated by students. The values of life are presented through literary works, both in the form of poetry, prose, drama, and film. Literary works can encourage students to be better learner, get to know culture, add insight.

Poetry learning in the Indonesian Language and Literature Education study program at STKIP Muhammadiyah Bogor has achievements in which students are able to understand and explain the development of Indonesian poetry, assess the structure of poetry, character poetry language, interpret poetry, apply poetry review methods, write poetry and publish it through book publishing, as well as developing poetry learning for compiling thesis.

Education has an important and central role in developing human potential. It is hoped that through education there will be transformations that can foster positive character, and change the character from bad to good[2]. Furthermore, character education is chosen as the main road for the formation of national character in the future. It is hoped that character education will form praiseworthy student behavior in line with universal values and noble cultural traditions[3]. Character education is at the implementation stage integrated with the learning process so that character education is not a teaching material nor is it a new subject.

The implementation of Poetry Learning lectures can also be directed at efforts to implement education and develop student character. Associated with the importance of character education is now believed to be the formation of personality that is also characterized. Character education must be integrated into various subjects according to the characteristics of each course. That is, character education can be integrated with a variety of subjects taught in class, also of course in the Poetry Learning course, must support the achievement of the formation of commendable character for students. This is one of the urgencies in developing teaching materials for Poetry Learning courses for students at STKIP Muhammadiyah Bogor.

Several studies that have been conducted regarding the development of teaching materials include the research entitled The Improvement of Fiction Study as a Teaching Material Based on Macassar Local Wisdom Integrated with Mobile Learning at FKIP Muhammadiyah University Makassar, researched by Haslinda et al [4]. This study uses 
the RIE ADDIE theory (Analyze, Design, Develop, Implement, Evaluation).

Other research was conducted by Mukh Doyin with the title Developing Poetry Teaching Materials in Elementary School [5]. This study aims to develop poetry teaching materials in accordance with learning guidelines including curriculum demands, student characteristics, and society in general. This research uses research and development ( $\mathrm{R}$ and D) methods to create products in the form of children's poetry criteria as teaching material in elementary schools. This method is simplified so that it only covers three main phases, namely (1) a preliminary study, (2) product formulation and development, and (3) product validation and dissemination.

Based on preliminary observations, the value of poetry learning courses in second semester students of the Indonesian Language and Private Education study program at STKIP Muhammadiyah Bogor is always below the average value of other courses relating to language and literary learning. This is due to the lack of books on literature available in libraries in the form of printed books and e-books, as well as the lack of maximum internet facilities in the campus area. The library complements the collection more with learning books than books on literature. In addition to the location of the Muhammadiyah Bogor STKIP in Leuwiliang, it is far from a bookstore that sells books on literature, especially books on Poetry Learning courses.

Based on this, research needs to be carried out in the Development of Character Education Teaching Material Learning Model Based on Character Education (Development Research in STKIP Muhammadiyah Bogor).

\section{LITERATURE REVIEW}

\section{A. Model of Borg and Gall Teaching Materials Development}

The Borg and Gall model is a common development model, in this study adapted to the conditions encountered. Language teaching means developing language skills and skills. In line with this, teaching materials are compiled in the form of books based on the opinions of experts. In this study refers to the Borg and Gall teaching material development model [6] with the following steps:

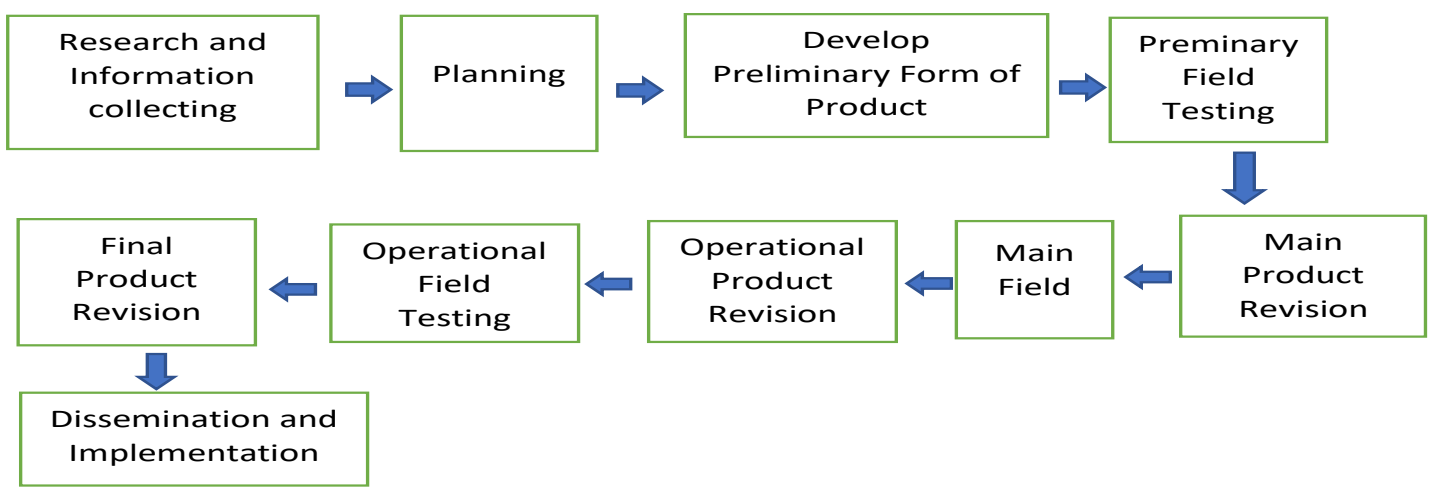

Fig. 1. Model of Borg and Gall Teaching Materials Development

\section{B. The Essence of Learning Poetry}

As a work of art, poetry can be studied from various aspects. The structure and elements of poetry can be studied, because poetry is composed of the structure and elements of poetry. Besides poetry can be studied from the type or variety, historical angle. Throughout the ages poetry has always experienced changes and developments. Riffaterre in Pradopo [7] states that poetry is always changing according to the evolution of tastes and changes in aesthetic concepts.

According to E. Kosasih Poetry is a form of literary work that is presented monologically, using beautiful words and rich in meaning. The beauty of poetry is determined by diction, rhyme, rhyme, and rhythm. The richness of meaning contained in poetry is caused by compaction of all elements of language [8]. The language used in poetry is different from what is used everyday. Poetry uses concise language, but the meaning is very rich. The word he uses is a connotative word that contains many interpretations and understandings.

One of the oldest genres in literary history is poetry. Poetry genre is divided into two main categories, namely narrative poetry and lyric poetry. Narrative poetry such as epic Long poetry, romance, and ballads. Narrative poetry has a story with a clear and structured plot arrangement. Whereas lyric poetry, shorter, contains about one event [9].

It can be concluded following the definition of poetry as above that a work of art is called poetry if it has the following characteristics: (1) prioritizing emotional rather than intellectual effects; (2) concentration and compaction of the problem presented and the way it is delivered; (3) is an expression of experience written in poetic language; (4) utilizing orchestral or musical elements or sounds in the form of rhymes and rhythms; (5) gives rise to influence, suggestion or motivation to the reader or listener or catharsis. Prose literary works as well as poetry-building elements, the media to express the thoughts and feelings of the author is one of the functions of poetry. Because poetry forms generally use kias or symbolic words and solid words make it more difficult to know. Therefore, to find out it requires the intelligence and foresight of the reader to interpret the figures of speech used by the poet. The statement emphasizes that understanding poetry is more difficult than understanding prose. In understanding poetry 
requires the audience to have sensitivity and precision in the language of poetry which is full of figures and symbols. C. Character Education

Education is the development or guidance derived from the word students, given the prefix and suffix, so that it becomes Education that has the meaning of action. Education is a guidance that is done consciously by educators on physical and spiritual development towards the formation of a good person.

The scope of education includes several aspects, namely cognitive, affective, and psychomotor aspects, both covering physical and spiritual aspects, harmoniously and integrally. To know which is good and which is bad, and for humans to do things according to the real proposition this is an educational goal. The big task of education is to make them smart and kind. Lickona explained, "Moral education is not a new idea. It is, in fact, as old as education itself. Down through history, in countries all over the word, education has had two great goals: to help young people become smart and to help them become good" [10]. Moral education is not a new idea. Character education to help students become intelligent and virtuous. Education not only makes someone smart, but more important is to make someone virtuous.

The Directorate of Higher Education explains character in general that demonstrates an ideal ethical or personal value system (good and important) for self-existence and dealing with others. Whereas in a special sense, character is typical good values (understanding the values of goodness and willingness to do good) contained in oneself and want to realize them in behavior [11].
According to Rutland in the proceeding of Hiski (2012: 96) [12] suggested that the character comes from the Latin root meaning "carved". Literally, character means its mental or moral quality, moral strength, or reputation. Character is a personality in terms of ethical or moral starting point.

The national education system law states that the goal of national education is to form intelligent individuals with personality or character so as to give birth to the nation's children who grow and develop with characters based on the noble values of the nation and religion. Character education means value education, character education, moral education, character education, it has a relationship with education. Character education can be interpreted as Education that develops noble character by practicing moral values.

The objectives of character education can be described as follows:

- Development of basic potential to be goodhearted, think well, and behave well

- Improvement of bad behavior and reinforcement of good behavior

- A cultural filter that is incompatible with the noble values of Pancasila

Broadly speaking, there are three components of good character, including moral knowledge (moral knowing), feelings about moral (moral feeling), moral behavior (moral action) [10]. All three can be described as follows:

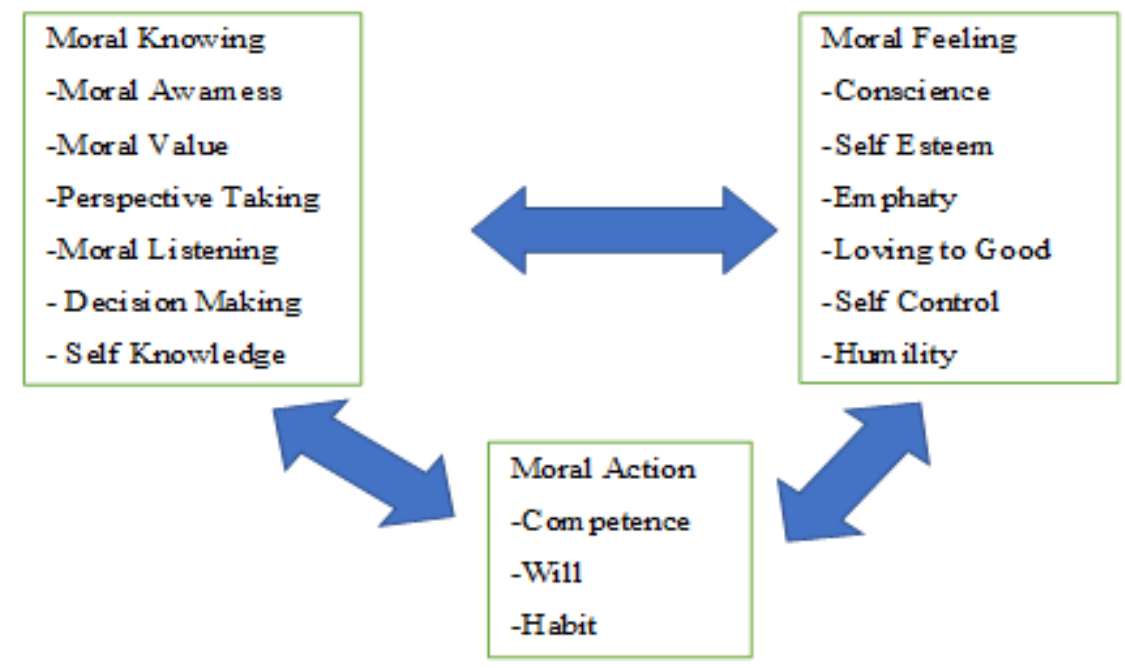

Fig. 2. Lickona's Component of Good Characters

In the picture above shows that good characters are interrelated between the three parts. Knowledge, practice, and habits are the stages of character development. Character is not limited to knowledge. Good character is not necessarily only owned by people who have knowledge. So combining the components above is very necessary in character education.

\section{Character Education in Poetry Learning}

Language learning is actually learning culture, The language-culture connection [13]. Teaching language means teaching something complex about habits, values, ways of thinking, feelings, and behavior of language users. When we learn languages, we learn the culture from which the language originated. Learning ways, ethics, and ways of communicating with others is part of language learning. The development of national cultural values is closely 
related to character education. Poetry learning is one of learning languages.

The values of a person's character education can be formed by learning Poetry Learning courses, namely poetry that expresses the use of language through expressing his feelings[14]. The use of language properly in accordance with the situation is a polite definition of language. Be considerate, maintain feelings, respect, get along well, be willing to give up, willing to sacrifice are the values of character education that can be formed in Poetry Learning courses.

The values discussed in literature include: a. religious matters (containing about beauty, sin, and salvation), b. problems of human destiny (related to freedom, impatience, and human spirit), c. problems of science, myth, and supernatural science, d. human problems with human concepts to do with death and stories, e. community, family and state problems.

Based on the description above, it can be concluded that the means of character education can be through the learning of Indonesian language and literature especially poetry learning courses.

\section{RESEARCH METHOD}

The development of this teaching material is based on the results of document review and needs analysis. Study the documents regarding the identification of competencies that must be achieved by graduates both at the end of the program and at each lesson. Needs analysis is directed at identifying the content of teaching materials desired by students and lecturers in relation to the characteristics of the target competency. The instruments used are in accordance with the syllabus and RPS of Poetry Learning courses at STKIP Muhammadiyah Bogor. The planning mechanism and the modeling of teaching materials in this study are reduced from the Borg and Gall models.

In developing the teaching material process data / information was obtained from lecturers and second semester students of STKIP Muhammadiyah Bogor. Information from lecturers is in the form of perception data, whereas from students in the form of learning experiences to be used as a track record in terms of the use of teaching materials.

The instruments used consisted of questionnaires, observation guidelines, and tests. The questionnaire was used to collect data from experts on the appropriateness of instrument need assessment. In addition, the questionnaire was also used to collect data on the perception of lecturers and students regarding teaching materials that have been used so far. Questionnaires are also used to collect data on lecturers' perceptions, experts on suitable teaching material profiles. Furthermore, the questionnaire is used to collect expert assessment data regarding teaching materials that have been developed. The aspects contained in the questionnaire for the final product evaluation refer to the Cunningswort evaluation instrument cited in Richards [15].

Observation is needed to collect data on the characteristics of teaching materials for Poetry Learning courses at the study site. Observation is also to collect data about students' experiences in using teaching materials in Poetry Learning courses during the development process.
Utilization of the test is to obtain information on student learning outcomes by using teaching materials for Poetry Learning courses before they are developed and after they are developed.

\section{DISCUSSION}

Some of the efforts that must be achieved to achieve the curriculum objectives of the Poetry Learning course at STKIP Muhammadiyah Bogor include quality lecture processes. The quality lecture process certainly needs to be supported by several factors, including the factors of lecturers, students, and infrastructure. Lecturers play an important role in lectures. Lecturers are required to have adequate competence. The competence of lecturers in Poetry Learning courses at STKIP Muhammadiyah Bogor is sufficient. Educational background The lecturer is a graduate of Indonesian Language and Literature Education, a Masters in Indonesian Language Education, and is currently taking doctoral education with a Language Education study program. That is, lecturers of Poetry Learning courses at STKIP Muhammadiyah Bogor, their educational background is linear. The results of the lecture evaluation analysis consisting of planning, processes, and assessments conducted by the lecturer are classified as good. The inculcation of the values of character education has also been applied by lecturers of Poetry Learning courses at STKIP Muhammadiyah Bogor.

In the lecture process, planning is also important. At the planning stage several factors that must be considered are syllabus development, RPS (semester lecture plans), and assessment. In this planning stage lecturers must be able to prepare teaching materials that will be used in accordance with the competencies to be achieved. The existing teaching material is actually already good, it's just not complete according to the RPS used in Poetry Learning courses at STKIP Muhammadiyah Bogor. This means that teaching materials currently available have not been able to answer the needs of lecture plans. In addition to teaching materials, lecturers are also required to be able to choose methods and approaches in lectures so that students can be active and can instill the values of character education.

Based on the results of the analysis and the results of the questionnaire filled out by students and lecturers, the results show that the need for teaching materials for poetry learning courses at STKIP Muhammadiyah Bogor in accordance with RPS is also based on character education. Teaching material also determines the success of lectures, therefore in its preparation it takes serious attention. Teaching material is an inseparable part of the syllabus and RPS of each subject according to the curriculum in STKIP Muhammadiyah Bogor. It can be said that teaching material is a description of knowledge, skills, and attitudes that must be mastered by students to meet the success that has been determined in accordance with the syllabus and RPS in Muhammadiyah STKIP Bogor.

Teaching material is an important part that must be prepared so that the lecture process runs well in accordance with the achievements of the course. Teaching materials must be in accordance with syllabus and RPS, so that students are more focused in the lecture process. Teaching materials are chosen as optimal as possible. There are 
several things that need to be considered in preparing teaching materials, namely the type, scope, sequence, and treatment of these teaching material materials. Teaching materials have a very strategic function for lecturers, because teaching materials can be used as a guideline in carrying out the lecture process as well as a standard course achievement. For students teaching materials are guidelines that must be mastered. Besides teaching material is also an evaluation tool for achieving mastery or mastery of the results of lectures.

The development of teaching materials for Writing Learning for the second semester at STKIP Muhammadiyah Bogor is carried out by considering several substances including the organization of presentation, use of language, and style. Teaching materials are presented sequentially and tiered according to the level of difficulty. Theories, assignments or exercises, and reflection activities are systematically organized. Organizing lecture material is based on pedagogical principles in accordance with syllabus and RPS.

Teaching material is designed by considering emotional, intellectual, language skills, and characteristics of student education. The organization of learning material is designed by paying attention to the graphic factor, to attract students' attention to the content of the reading. Factor value of character education also did not escape attention in designing teaching materials for Poetry Learning courses for semester II at STKIP Muhammadiyah Bogor.

Teaching material is written from several sources, for example from newspapers, magazines, internet, journals, etc., so that students do not feel monotonous and bored. Teaching materials are also designed to involve students to be more active in lectures. Of course, by promoting the values of character education.

The structure of the development of teaching materials is in accordance with the syllabus structure and lesson plans in the Poetry Learning course at STKIP Muhammadiyah Bogor. The steps of the lecture process are organized into three parts, namely the introduction, core, and closing. In the preliminary activities, teaching material in the form of information to understand the material conceptually, for example about the theme of the material, or explain the competencies that will be mastered by students on the material.

In the core activities, students conduct various activities or training which are carried out in stages to form an understanding and ability in accordance with the achievements of the Learning Writing course which is certainly based on the syllabus and RPS at STKIP Muhammadiyah Bogor.

For the closing activity, students reflect on the teaching material that was learned during the core activity. In addition students can enrich, and create the experience of lectures.

In the aspect of language, the development of teaching materials must pay attention to the use of language that will be written in the material presented. The language used must be easy to understand and communicative, so that the author's intent is conveyed clearly to students and lecturers as users of the teaching material. In this case, language is very important as a conveyor of information, directing instructions or commands, developing tasks or exercises, evaluating activities, and hinting for reflection activities. Some of the functions of the language will be successful if using communicative language, the language of choice of words and sentence structure is clear so that all information contained in the teaching material can be understood by students.

In addition, attention is needed in structuring the development of teaching materials. Some things to consider include layout, use of color, use of letters, pictures or illustrations, and print sizes of teaching materials. Each material several things structuring in the development of teaching materials is very necessary. The development of teaching materials for Poetry Writing Learning courses for the second semester students at STKIP Muhammadiyah, has its own uniqueness. Teaching material that researchers created is teaching material for Learning Learning Writing poetry based on character education in accordance with the syllabus and RPS in STKIP Muhammadiyah Bogor. The value of character education is also in accordance with the objectives of national education in Indonesia.

The development of teaching materials is explained by inductive patterns. The value of character education takes precedence in the development of this teaching material. The stages of developing this material are based on orientation activities, concept exploration, concept interpretation / discovery, and concept application.

The role of lecturers as facilitators, means that lecturers no longer dominate in lectures, but students must be active in lectures by searching for and digging information based on the material being studied. Textbooks can also be used as a reference and source of information for students and lecturers. Aside from being a facilitator, the lecturer also acts as a motivator, a learning companion for students, and a place to ask if students have difficulty finding information. Lecturers also play a role in training students to be independent and able to discuss or solve their own problems so they become more mature and responsible. The exercises conducted by these students are part of the value of character education.

In accordance with the objectives of developing teaching materials for character education-based Poetry Learning courses for the second semester at STKIP Muhammadiyah Bogor, these teaching materials are declared feasible, and can be used in lectures. This teaching material has been through a series of tests, from the trial test, expert test, field trials, to effectiveness tests. So it is believed that these teaching materials and instructions for using teaching materials can be used to improve Indonesian language skills especially in Poetry Learning courses.

From the small group and large group tests, it can be concluded that there is an increase in the active participation of students in the lecture process. Students are motivated, enthusiastic, enthusiastic, and physically and mentally active in participating in the whole series of lecture processes. Then during the implementation of the teaching material effectiveness test that the quality of the 
process and the quality of the results of lectures there was a marked improvement.

The development of teaching materials is intended to meet the needs of Poetry Learning-based character education courses for second semester students at STKIP Muhammadiyah Bogor. The development of teaching material products can be used to develop students' knowledge, skills, reasoning, and to instill the values of character education in accordance with the objectives of Indonesia's national education. This teaching material product can also be used as a reference for Poetry Learning courses in technical matters from the lecture process to the evaluation process. The results of lectures by integrating the values of character education that appear to increase changes in student attitudes towards better.

\section{CONCLUSION}

Based on research and development of teaching materials that have been done, it can be concluded that the need for the development of teaching materials for character education-based Poetry Learning courses for semester II students in accordance with the syllabus and RPS of the courses in STKIP Muhammadiyah Bogor. Development of teaching materials is carried out in the form of teaching materials consisting of introduction, content or material, assignment or training activities, assessment, and reflection. Some of the stages passed include the product test in terms of students, has been declared feasible and can improve the quality of student lectures and the inculcation of values of character education. In terms of the lecturer who is also a user, the product development of this teaching material is fit to be used as a lecture guide.

\section{REFERENCES}

[1] R. Antika, "Poetry in Efl Classroom," Tell-Us J., vol. 2, no. 2, pp. 20-35, 2017.

[2] C. Pattaro, "Character Education: Themes and Researches. An academic Literature Review," Ital. J. Sociol. Educ., vol. 8, no. 1, pp. 6-30, 2016.

[3] W. S. Mak, "Evaluation of a Moral and Character Education Group for Primary School Students," Discov. Student E-journal, vol. 3, pp. 142-164, 2014.

[4] H. Haslinda, M. R. Tang, and A. S. Syamsuri, "The Improvement of Fiction Prose Study as a Teaching Material Based on Makassar Local Wisdom Integrated with Mobile Learning at FKIP Universitas Muhammadiyah Makassar," J. Lang. Teach. Res., vol. 8, no. 5, p. $915,2017$.

[5] E. Rosmayanti, T. Supriyanto, and A. Sunarso, "Developing Poetry Writing Teaching Materials Based On Environment and Local Culture for The Fourth Graders," J. Prim. Educ., vol. 9, no. 1, pp. 25-32, 2019.

[6] and B. W. R. Gall D. Meredith, Gall P. Joyce, Educational Research: An Introduction, Seventh Ed. New York: Pearson Education, 2003.

[7] R. Pradopo, "Ragam Bahasa Sastra," J. Hum., vol. 0, no. 4, 1997.

[8] engkos Kosasih, Apresiasi Sastra Indonesia, no. JAKARTA TIMUR. 2008

[9] M. Klarer, An Introduction to Literary Studies. .

[10] T. Lickona and M. Davidson, "Smart \& Good High Schools," Learning, p. 227, 2005.

[11] K. C. Tsai, "Bring character education into classroom," Eur. J. Educ. Res., vol. 1, no. 2, pp. 163-170, 2016.

[12] M. A. Fresky, "Peran Sastra dalam Pendidikan Moral dan Karakter Anak Bangsa," 2019

[13] H. D. Brown, Prinsip Pembelajaran dan Pengajaran Bahasa
(Terjemahan oleh Noor Cholis dan Yusi Avianto Pareanon). California: Pearson Education, 2007.

[14] D. Maria and S. Darta, "Character Building through Poems : An Interactive Approach in Teaching Poetry," 2011.

[15] J. C. Richards, Curriculum Development in Language Teaching. Cambridge: Cambridge University Press, 2001. 